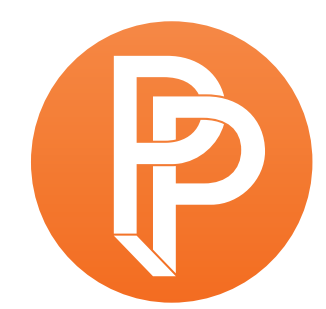

PERFORMANCE

PHILOSOPHY

\title{
A 'WHAT IF' EXERCISE: ON THE INSTITUTION OF THE ART SCHOOL ${ }^{1}$
}

\author{
SILVA BOTTIROLI DAS THEATRE, AMSTERDAM
}

\begin{abstract}
Every time we speak of the 'institution' as other than 'us', we disavow our role in the creation and perpetration of its conditions [...]. It's not a question of being against the institution: we are the institution.
\end{abstract}

Andrea Fraser, "From the Critique of Institutions to an Institution of Critique"

$(2005,106)$

This text attempts to organize my thoughts responding to a set of questions about how we can practice an art and specifically a theatre school, how we can do and undo it, taking into account how institutional structures have power over us, and how we have agency within them. Following Andrea Fraser's line of thought (Fraser 2005), I believe that we are the institution: we have agency within it and-no matter which position we speak from-we have a role in the creation, perpetration and also transformation of the conditions it provides. At the same time, while working within an institutional framework we all experience how much institutions have power over us. As a matter of fact, every institution allows certain things and not others, separates an inside from an outside to establish what and who is part of it and under which conditions, and dictates how people can and cannot behave within it. 
With the risk of giving them a form of agency that is normally associated with human beings only, we may argue that institutions perform in the social realm, responding to their own specific way of thinking. Hence, understanding how institutions think is very important in order to exercise our agency within them effectively and, consequently, to be able to bend them, hybridize, challenge, betray or queer them. By approaching artistic institutions as "thinking entities," my reflection intends to contribute, offering a specific perspective on art schools and art education, to the discourse already opened, among others, by the collective book How Institutions Think: Between Contemporary Art and Curatorial Discourse (O'Neill, Steeds, and Wilson 2017) that, taking the famous text by cultural anthropologist Mary Douglas as a starting point (Douglas 1986), collects various contributions about contemporary artistic institutions. In the performing arts field, a whole discourse recently started to open up about the institution as a "fictional entity," and about the possibility that fiction offers to approaching how an institution thinks and to rethinking it. ${ }^{2}$

This discourse is embedded in the field of curation, a set of practices and theoretical tools that is relatively new in the performing arts. Only in recent years, curation and curating started being discussed in the theatre field, initially bending the conceptual tools developed within the visual arts, and only later building new terms, framing particular practices, raising specific questions. The publication of the issue Curating Performing Arts of the Croatian magazine Frackija in 2010 and the international conference Beyond Curating at PACT in Essen in 2011 mark the moment that this conversation started developing in Europe, creating a new discourse and a different understanding of practices related, among the others, to institutions and instituting processes. More recently, the theatre field seems to be more intrigued than ever by institutions as a subject. The book Turn Turtle! Re-enacting the Institute (van Campenhout and Mestre 2016), the symposium and free school around The Fantastic Institution organized by BUDA arts center in Kortrijk in 2017 and 2018, and the Performance Philosophy conference in Amsterdam in 2019 are just some of the strongest indicators of this phenomenon. ${ }^{3}$

In fact, I am proposing to look at institutions from two complementary perspectives: how they think, and how they perform. These two layers are obviously intertwined in the life of institutions. We can of course move from the one to the other, sometimes blurring their borders, but I believe it is important to be aware that institutions can only perform according to the way they think. Understanding how they think is how we can anticipate how they can or cannot perform in the artistic and social realm. From there, I believe that it is at the intersection between their thinking and their performing that we can intervene effectively within institutions.

Artistic education as a field, and the art school as the main subject within it, have been present within the debate about artistic institutions since its beginning, as a crucial subject in a field that thinks itself as progressive, research-led, experimental and committed to the production of the future. Nevertheless, a specific line of thought about art education within contemporary performing arts is not implemented yet, although the school and the academy are, as Charles Esche suggested, "where it all begins" (Esche 2007, 1). 
Institutions are always made to set conditions for something and always do something. In the arts field, the institution can, for example, serve to transmit a legacy or a tradition (the museum, the library, the repertory theatre...), produce new forms (the arts centre, the residency place...) or broaden the encounter between the arts and a public (the festival, the biennial...). Furthermore, all institutions are the result of a negotiation between different subjects and the discourses that inform them. This is also the case with the art school, which is positioned at the intersection of art production and education, and responds to many more systems (political, financial and so forth).

Like any other artistic institution, a school is shaped in order to frame, secure and support specific values. Approaching it from the perspective of what it sets conditions for and what it does is a way to deconstruct the idea of the art school, and to become able to think it anew, becoming aware of what it is, how it operates, what it makes possible or impossible. By creating a tension between the institution of the art school and the agency we as individuals have in thinking and rethinking it, I am trying to identify the space from which we can operate differently within the institution of the school, and possibly from which to practice the school otherwise. This process requires at the same time a critical exercise and imaginative bumps: I will start from the first, to then tap into the latter.

My experience within the theatre school and my knowledge about it is precisely situated within DAS Theatre, the former DasArts, founded in Amsterdam by artist Ritsaert ten Cate in 1994 as an independent organization and later becoming part of the Amsterdam University of the Arts in 2009. All my thinking-and the very motivation of rethinking the institute of the school-is rooted in this extraordinary place, in the deep transformation it experienced in the last decade, and in the desire to imagine it anew as a response to and as a provocation for the theatre field of today. However, some fundamental values are shared by all the theatre schools (academies and universities) that are attempting to reimagine or reinvent themselves in relation to an artistic and political framework radically different from the one that first produced the institution of the art school a couple of centuries ago. ${ }^{4}$

To tackle what the institution of the school is, it may be useful to go back to the original meaning of the word, although we must be aware that it has undergone many transformations over time. In ancient Greek, skolè (the word for school) denotes, first, "a time of leisure" (as opposite to other, more instrumentalized, times), and only consequently means "a place for learning" and "a forum for discussion." So, like any other institution, the school is defined by three vectors: time, space and forms of relationships oriented towards specific aims.

From the perspective of time, we can approach the school as a complex set of different temporalities, that cross each other. Time can be experienced at school not only as duration, but also in its density and in its speed. More often, several temporal dimensions intertwine and cut through the particular time of the school as an institution, one that is instituted in time and requires re-institution over time. Consequently, time operates within the school as a manifold entity, capable to affect profoundly the life and dynamics of the institution itself. 
From the perspective of space, a school always needs or produces a place, a specific locality where its participants can come together. In that sense, we could say then that a school is always local, no matter how broadly international its population is, or how deeply networked the institution is.

The specific sets of relationships of the school seem to be, though, the most important vector defining its singularity. I will thus focus on them, and approach time and space from the perspective of relationships as well.

\section{Nothing goes one way: Art schools as sites of agonistic pluralism}

\section{Relationship among all things appears to be complex and reciprocal-always at least two ways, back and forth. It seems that nothing is single in this universe, and nothing goes one way.}

\section{Ursula Le Guin, “Deep in Admiration” $(2017,15)$}

Schools produce a complex set of relationships, and these are always reciprocal. Art schools, in particular, are meant to be places where a new generation of practitioners can and must imagine themselves anew within the context of formal education. The school offers a support structure for artists to imagine themselves as individual and collective forces that can shape the art field and have an impact on other spheres. It offers a unique space where students can experience a structural safety, have time to focus on their work and can make use of facilities to explore, deepen and broaden aesthetic forms and research questions. Graduate and post-graduate institutions, in particular, offer conditions for an in-depth peer exchange and forms of encounters based on learning rather than on teaching.

Two main sets of relationship seem to be crucial in these environments: one articulates the peer exchange between participants as students and as artists, while the other is connected to the encounter between the students as individuals and as a collective body, on the one hand, and the school as an institution, on the other hand. This latter is normally informed by the assumption that the students are not part of the institution. This assumption, that per se is false of course, is actually fuelled by the fact that students often experience a perceived and factual lack of agency in the school, and tend to be seen, and therefore to become, sheer consumers of what the school can offer rather than co-authors of what it can generate.

Both these relationships are complicated further, in graduate and postgraduate education, by the fact that students are, in most cases, professional artists already. This means that their peer relationship is actually doubled: they are peer artists and peer students at the same time. But also their relationship with the teachers or tutors is of a double nature, since for their teachers they are not students only, but also (younger) peers.

Like many other institutions, the art school produces a complex community, traversed by a variety of different relationships. But, different to others, this is, per definition, a temporary community. People don't stay at the school forever, and the school is meant to be a place for transition, for 
moving from one state to another. Therefore, the time spent within the art school is very dense, and traversed by the particular demands that students have towards the school itself (to make them better artists, to broaden their professional networks, to consolidate their position within the field, to be a shelter and provide time and safety for them to stay in a research mode, for example).

All these are legitimate demands produced and reinforced by the current policies of art education, by the ways of operating undertaken by the institution of the academy and through its relationships with the professional field. Nevertheless, I believe it is important to deconstruct these demands and speculate on what the school could or should be there for, what it could or should set conditions for.

I believe that art schools exist to offer specific support structures for new generations of artists to explore and strengthen their means of engaging imaginatively with the complexity of the world. This is something they, as artists, are doing anyway. They don't need the school for that. The difference is that, at school, they are offered a particular environment that, on the one hand, is meant to be extremely safe and supportive and, on the other, by referring to the structures of formal education, confronts them with hierarchies, power structures, timelines and assessment policies. Are these two features compatible? How can one deal with this ambivalence?

One of the crucial purposes of the art school is, in my view, to produce this friction between imagination and rules, freedom to explore and pedagogical structure, research and artistic production. I am not sure how many artists are fully aware of that when they apply for a school, and I don't think that the friction the school as an institution is producing is always fruitful, but I am convinced that it can be positive and somewhat generative of conversations and adjustments of policy. Art schools can be a place of productive tensions and I believe that these tensions are actually one of the support structures that they can offer to artists, since they contribute to create a pluralistic and diverse environment. I am proposing here an agonistic view on the art school, suggesting that schools are sites of the political and that we should approach them as such. ${ }^{5}$

In fact, schools can be approached from an agonistic perspective because they are always pluralistic: different agencies cooperate in making the school, and different, often contradictory, agendas operate within them. The school as an institution is always a place where 'we are many' and where many singular perspectives are brought together. Moreover, this "many" is not to be misunderstood as a simple collective, because power relations and asymmetrical positions do exist within formal education. In this respect, we could look at the art school as a micro-society, a structured, political temporary community where we can experience ourselves as individual subjects co-creating a complex societal structure, continuously colliding with others' propositions and perspectives.

In her text Institutions as Sites of Agonistic Intervention, Chantal Mouffe advocates for the need for critical artistic practices to engage with institutions, and artistic institutions in particular, by "bringing about agonistic spaces" (Mouffe 2013a, 69) and thus making them what they could be: "agonistic public spaces where [the current] hegemony is openly contested" (Mouffe 2013a, 70). The question is how to use existing institutions to foster political forms of identification and, in 
parallel, how to make existing conflicts productive. Both these perspectives apply to the idea and the practice of the art school that, like any other artistic institution, "by staging a confrontation between conflicting positions [...] could make a decisive contribution to the proliferation of new public spaces fomenting agonistic forms of participation where radical democratic alternatives to neoliberalism could be imagined and cultivated" (Mouffe 2012, 73-74).

The concept of agonism is introduced by Mouffe as opposite to the liberal understanding of negotiation, on one hand, and the call for consensus, on the other. Performing an art school as the agonistic space that it could be is not easy. It requires a constant deconstruction and reconstruction of the idea of the school itself, an openness to reconsider one's own positions and yet also a confidence that any political stance the institution takes and proposes, as well as any position embodied by any of its constituencies, can contribute to the production of a democratic pluralism. Although we can agree that creating spaces of agonistic pluralism is crucial in the current conditions set for art production in times of Post-Fordist capitalism and neoliberal ideologies, the exercise of engaging with it is not linear and requires a consideration of the sites where, in each institution, agonism can be found and cultivated.

One particular feature of schools that contributes to their political agency is the fact that even though they do choose their staff members and their students, and therefore they are not open to everybody, schools are per se open to anybody. Hopefully within any school you will find a community of people who, no matter what their positions within the institution are, are committing themselves to the difficult and necessary exercise of living together. We could look at schools as a very privileged place for the exercise of political negotiation, since they always require a constant negotiation rules and practices, mediating between different needs, making compromises, questioning one's own beliefs and values, exercising radical forms of listening. ${ }^{6}$ The point is rather how negotiation can avoid becoming a neoliberal practice where everything can continuously be negotiated all over again, and how singular positions can get agency and collectively contribute to challenge the political hegemonies that the school itself, and the contexts in which it operates, have established.

Here, the collective dimension of the school comes into play, and offers some perspective. In fact, art schools are places where artists study, work and research alongside and with each other. The encounter between practitioners who research and work in different disciplines and relate to different socio-cultural frameworks is not immune to misunderstandings and frictions. But a school where this encounter occurs is a unique space where not only new art forms, but also new cultural practices can be researched and tested. If this is the case, then the impact that art schools can have on the art field at large is huge.

Maybe it is indeed thanks to the sets of tension that traverse it that the art school can, as the complex institution that it is, stand for its principles and resist the hegemonic view of art as an ongoing production and circulation of works and of art education as a set of tools for artists to improve their signature and therefore acquire greater value in the art market. By providing the possibility of thinking through practice, and therefore exploring art as a subject of reflection rather 
than only as an object of reflection, the art schools value art practices in their capacity to formulate research questions and explore them within the specific means of art. One of the political stances of the school, we could argue, is indeed to support this capacity, and provide visibility to the specific form of thinking that is produced by the artists with their work, presenting it for what it actually is: a practice and a reflection, at the same time. One of the agonistic spaces that art schools can produce is indeed this space for rethinking art beyond any binary opposition between theory and practice, subject and object.

Such an agonistic dimension is in my view one of the fundamental features of art schools. The risk is that it evolves into antagonistic tensions that could find a fertile ground in the institution of the school. Being confronted with an existing structure, as in the school, can, and normally does, produce a form of discipline and obedience, on the one hand, and a form of rebellion, on the other. When this tension takes place across symmetrical and asymmetrical power relationships, the result-unwanted, but real-is that a school often produces forms of antagonism.

I have the impression that we are increasingly experiencing an antagonistic polarization within art schools. This polarization seems to reflect the contemporary socio-political atmosphere, ruled by inequalities and injustices, fuelled by a narrative of scarcity and competition and by a very broadly spread mistrust, if not aggression, towards the very idea of institutions. Institutional critique seems to have played an important role in shaping the behaviour patterns of the encounter, collaboration or coexistence, of artists and artistic institutions in particular, and obviously schools are not immune to that.

It is possible that the polarization within art schools can produce the same harmful process of simplification that is flattening perceptions of reality in other fields of our collective lives. This is a serious concern. But, if we push the concept of polarization further, it can turn into something else, something even desirable for the performing arts field in this very moment. As a matter of fact, schools are one of the few institutions in the arts field providing a space for such polarizing relationships. They provide a space for friction, for conflict even. No matter how progressive and open the program is, the school as such confronts all its constituencies with a clear hierarchical structure and with a set of rules that can be subject to negotiation but are already instituted.

In a working field that understands itself as a context where all relationships are fluid, everything is debatable and negotiable, collaboration is a key resource and affective labour is a reality, art schools can represent an exception, as their vision can be less friendly with contemporary policies. The contemporary theatre field is extremely critical toward current neoliberal policies, but at the same time it is perfectly reproducing, and even improving, them to the point that it is considered to be one of the fields where policies of self-exploitation are most successfully tested. The contemporary artistic field is characterized, as many more fields, by a dangerous liquidity, where all relationships are blurred and artists often end up being complicit with the structural procedures that exhaust them. ${ }^{7}$ There is very little space in the artistic infrastructure to exercise conflict, to radically disagree, and even less space to disagree and still work together, from different and irreconcilable positions. 
At school, on the contrary, this is to be possible, no matter what. I am not pretending that this is always the case, but the possibility of radical disagreement should be part of the fundamental, unnegotiable form of safety that a school must offer. A safety that goes way beyond the sense of physical and psychological safety of being respected and valued as individuals, without any form of discrimination due to class, race, colour, gender or sexual orientation. Once this basic safety is taken care of by the institution itself, then the structural safety that the art school is to provide to students is actually for them to be free to pursue their research and make their work, no matter what forms, aesthetics and politics they perform.

\title{
Not an individual affair: Art school as entangled subjects
}

\begin{abstract}
To be entangled is not simply to be intertwined with another, as in the joining of separate entities, but to lack an independent, self-contained existence. Existence is not an individual affair. Individuals do not preexist their interactions; rather, individuals emerge through and as part of their entangled intra-reality.
\end{abstract}

Karen Barad, Meeting the Universe Halfway (2007, ix)

An art school is never an independent subject. It is part of a wider environment. It operates at the intersection of art and education, depending on and contributing to both these fields. It is intertwined with the art infrastructure locally and globally, with the policies of its funding bodies, that are often public, and with the developments of the artistic and cultural field. These sets of relationships actually mean something more than just being intertwined with another: the art school is entangled because it lacks a self-contained existence. It operates and thinks with and within a complex environment, it is affected by it in ways that are not always predictable, and it affects its environment in many ways, connected to the concrete impacts that a school may have.

This entanglement has several dimensions. One is the broad socio-political framework in which art is questioned in its legitimacy as a cultural practice and in its capacity to strengthen citizenship and democracy, contributing to a progressive, liberal development of society. All over Europe, art's role is currently often undermined or dismissed, in favour of a very functional approach to social dynamics. Art schools have agency within this field, since they are one of the few institutions that can render visible the work of art, but are also heavily affected by it, and often seen as useless places where a privileged minority cultivates their hobbies. One possible way of becoming conscious of entanglement is, for art schools to combine their agendas with the agendas of other institutions and individuals, to propose themselves as allies and accomplices for other subjects that pursue different, but interconnected aims. A school's accountability, as any other institution's accountability, is always relational and reciprocal. We operate within a circulation of responsibilities and agencies, and it is our task to embrace them. Some examples in this sense come from self-organized and artist-run initiatives. The Silent University initiated by artist Ahmet Ögüt as a nomadic project, involves refugees and immigrants who are not able to share and transmit their knowledge in the countries where they relocated, thereby establishing a strong link between art, knowledge production and immigration policies. The Unidee project organized by 
Cittadellarte in Biella, Italy connects artistic and curatorial research with the societal issues experienced by an area transitioning from a flourishing industry to a post-industrial economic system. The programmes created by Tania Bruguera in Cuba and by Chto Delat in St. Petersburg testify, in different ways, to the deep entanglements between art education and political frameworks, within and beyond the activist attitude of their founders.

The local dimension of the art school also contributes to complexify its entanglement, since the school operates locally and globally at the same time, as one of the subjects that can help shape artistic mobility and a transnational, moving artistic community, confronted with issues that include the psychological, social and environmental consequences of a model based on an exasperated mobility. When committed to engaging with its local dimension, the school as an institution, however, is to question its foundations: for whom does it exist, who can be part of it and have agency within it? How does it plan to preserve qualitative exchanges, and yet participate within a local context that is broader that its artistic discourse? ${ }^{8}$

It is often uneasy for art schools to engage with, and be relevant within, a specific local context. Nevertheless, the friction between the local and the global field that the art school is part of, is possibly very generative of necessary conversations that reframe the understanding of the local and the global. How can art schools relate to the particular forms of global community that are there in the arts field, with artists fleeing from many countries in search for better conditions in which to work and sustain their practices? What role can schools play, as transnational temporary communities of artists, within a field that considers mobility as a key resource?

I will not enter the complex social and cultural aspects of this situation, one that we should be particularly committed to in Western Europe where for several reasons many artists decide to relocate, hoping for a more sustainable, fair and friendly working field that they don't always find. ${ }^{9}$ Rather, I would like to suggest that, in this context, art schools can and must become sites of an important transnational exchange, one that entails a potential impact on the ways people imagine and produce the art forms of the future. What is the potential of the transnational community of artists making research and working alongside each other in artistic institutions based on peer exchange and feedback culture? How can the potential of such communities be actualized? In these kinds of context, participants not only develop their artistic universe, deepen their practice and broaden their forms of expressions. The curriculum also invites them to collaborate with each other as performers, technicians, external eyes or dramaturgs, providing a collective environment based on support and facilitating mutual exchanges and influences.

As a matter of fact, very often art schools cherish a narrative of individual makers, designing programs that are based on the students' individual ownership, driven by their specific research questions and art practices, and meant to strengthen them as individual voices. What if, instead, we look at art schools as collective entities and unique environments that nourish a sense of multiplicity and a desire to undertake adventures together? What if, for example, students could graduate with collaborative or collective works, instead of with creations valorised as the product of an individual with a discernible set of pre-determined skills? What forms of empowerment could 
this shift produce, and what would its consequences be within the broader art field, once students go back to it as makers, pursue their artistic practices, intervene in the existing institutions and establish the support structures that they have learned as being important for artistic research and practice?

When focussing on the cultivation of a transnational community of artists as students, schools are, much more than any other institution in the art field, places where different artistic idioms meet and develop alongside and with each other. They are sites of mutual influences, where the development of one's own artistic work unfolds in a form of commonality rather than in a splendid isolation. What this commonality can be about, and precisely which forms of togetherness can be fostered within the art school, are questions worth exploring, also in relation to how, from being a place for commonality, the art school can realize existing entanglements with other subjects.

All entanglements necessitate a form of interdependence, of non-homogeneity, and in the end of difference. Being entangled does not mean being or becoming identical to the other subjects one is intertwined with. On the contrary, cultivating one's coefficient of diversity, one's autonomy (to the extent to which autonomy is possible) is therefore as important for an art school as it is to be permeable and porous to the entities that it lives and thinks with. Moreover, this coefficient is needed to keep a distance from the current, ever-changing policies that rule the institution of the school, and from the political agendas imposed by the market and by the public and private powers that have influence on art education. It is from this position of slight distance, from this feeling of non-belonging and from this stubborn cultivation of its own difference, I believe, that an art school can transform the tensions that traverse it into productive ones. Still, questions remain. How to operate within a given set of conditions, infiltrating different discourses in it? How to pursue the values attached to a pluralist institution for art education and production, no matter what the current values are that are circulating in the fields of academia and art market? How not to emphasize the narrative of the individual artists competing for resources, but rather nurture a sense of collective endeavour to make the working field more equal and just?

\title{
A future the challenges of which we just cannot imagine: Art schools as an engagement with the present time
}

\begin{abstract}
We know that those who enter university today belong to the generation that will have to face a future the challenges of which we just cannot imagine. [...] Can we claim that what we are proposing them meets, or even vaguely meets, this situation?
\end{abstract}

Isabelle Stengers, "'Another science is possible!' A plea for slow science" (2011)

Graduate and Postgraduate artistic education uses to think in terms of knowledge generation and exchange rather than of knowledge transmission, but it is undeniable that each school has a particular legacy, and one of its core missions and key activities is to transmit it. In the best-case scenario, transmitting goes hand in hand with questioning or challenging this legacy, in the attempt 
to keep it, and the school as such, permeable and porous to an ever-changing artistic, social, political environment that confronts us with philosophical, ethical and aesthetic issues.

If we look at them from the perspective of the legacy they carry, schools are "forces of the past" (Pasolini 1964). It is up to us to constantly explore what this past may mean today, how we can access it and use it as a force to shape the present and produce the future. I am not particularly keen on celebrating the past as such or its abstract values, but our commitment towards the production of the future risks to be a form of escapism in a present time that we may legitimately consider to be quite dark. In order to shift the focus from the future towards the present and engage with it, we cannot avoid considering the forces that have shaped it.

The supposed proximity between the past and the present should not only be understood in terms of continuity though. Every art school's function is to secure the transmission of knowledge. Every school is based upon a certain tradition and has a specific legacy that connects it to something that comes from the past. How can schools, and the forms of knowledge production and sharing operating within them, be not an image of the past, but rather a force of the past, meaning a force capable of moulding the present, coming from a different time and place but operating here and now?

Understanding the past as a force within the present time may help us to think the relation with the legacy not as a way of repeating the past, but, instead, as a means of producing cracks in the present, digging holes or making gaps through which other forces-e.g., potential pasts and potential futures- can access our present time and fertilize it. ${ }^{10}$ I see this as another form of friction, another positive tension, that the art school can produce and sustain via the collision between its particular culture, vocabulary and system of values, and the students that enter it and rightly demand the school to make sense for them, and to change with them.

Isabelle Stenger's famous plea for slow science is of course a prominent reference in thinking slowness as a necessary asset of research and knowledge generation. Her plea speaks to a scientific community that is in many respects very far from the community of artistic research. Like philosophy, as opposed to "fast science," art is per definition committed to "take the time needed to formulate questions" (Stengers 2011). Art's and artists' legitimacy is often understood as related to their capacity to build a form of reflection that is barely achievable by any other field, including academic research. As a society, we support the arts and the artists because they do the job that we as individual citizens and communities can hardly do: the job of thinking, formulating questions and exploring them, not necessarily with the purpose of answering them.

What if we understand art as the set of human practices exploring what is unknown, not to make it known, but to maintain it unknown, obscure? What would the political potential be, of an activity that has no aim but to understand itself as a means with no ends? ${ }^{11}$ In this respect, art does operate, likewise philosophy, as the slow science that Stengers is claiming for. Stenger's plea is actually meant to radically question the bonds between scientific research and capitalist markets, and obviously the nature of these bonds cannot be answered by art. Nevertheless, art and philosophy are the tools and the environments that, quoting Stengers, could "enable scientists to 
accept what is messy not as a defect but as what we have to learn to live and think in and with" (Stengers 2011).

In order to accept the complexity that "we have to live and think in and with," it is necessary to create the conditions that allow us to fully engage, intellectually and imaginatively, with the real. ${ }^{12}$ The first condition that is needed for such thinking is time, a continuity of time that encourages us to patiently sit and wait, to contemplate and to observe, until "the line of thought dip[s] deep into the stream" (Woolf 1929).

It may sound naïve to claim this kind of time in a working field ruled, as every other, by productivity and efficiency. Our current working conditions are meant to prevent us from thinking, in the sense of dipping deep and exercising imagination. But, as we know, "think we must" (Woolf 1938).

What if, then, we look at art schools as a site for such thinking? What kinds of temporality should they provide to allow artists to research and work outside or beyond the temporalities that rule the contemporary art field? In her article The Project Horizon: On the Temporality of Making, Bojana Kunst criticizes the "projective temporality" of today's art field, suggesting that within the regime of the project "we don't actually move anywhere, because [...] no difference is produced. In a project, an equilibrium between the present and future is set up, in the sense that whatever has yet to come is already projected in the present" (Kunst 2012). According to Kunst, "temporality is at the core of the production of difference. It is the material of social and aesthetic change [...]. Art production and creation must therefore rethink the relation between temporality and its production, and find new ways in which to push the time 'out of joint."' If they should respond to the current temporalities that are available within the art field, in the perspective of complementing them, the art schools should definitely propose a temporality freed from projects and deadlines, a sort of continuity where the time of the present can be inhabited again and a relation with the future can be set, beyond "the speculative balance between that which is and that which has yet to come", always according to Kunst. Could we imagine such a school? An art school with no assignment, no writing of plans, reports and reflections? A school that does not only practice integral assessment, but also performs evaluation as a constant practice unfolding parallel to the students' learning trajectories? What would that kind of art school confront its students with, how would it represent a productive challenge for them and for the working field?

It is difficult, if not impossible, to imagine an art school free from the logics and temporality of the project. Not only because of how the school itself operates, but also because of how being a student is often, for the artists, one of the many identities that they have to perform, juxtaposing or connecting them to each other, in order to maintain their professional position during the time of their studies. Nevertheless, the urge to create radically different temporalities for the art school is real, and the limits into which we bump once we try experimenting it is just a signal that deconstruction and reconstruction of the idea of the school are not sufficient, and imaginative bumps are needed to create a virtual space where other scenarios can be imagined. 
I propose that instead of treating the interminable question of the capacity to act in terms of 'possible versus impossible', we examine what it might mean to institute 'otherwise', politically and performatively, 'as if it were possible.'

\section{Athena Athanasiou, "Performing the Institution 'As If It Were Possible"' $(2016,679)$}

Athena Athanasiou's proposal could be adopted as a manifesto and as a methodology, based on the tactic of the "otherwise" and the "as if," as opposite to the hopelessness of the "due to" and to the strategy of the "against." We must acknowledge that we depend upon the institutions, even when we claim to be outside of them or against them, when we don't practice them, leave them behind or try to build alternatives to them. But we don't only depend upon them. We also shape, affect, deconstruct and construct them over and over again. We think them, and we perform them. There is no outside of the institutions, and, despite how terrible this might sound for some of us, it is also a radical call to engagement to feel involved, to claim our agency and to practice it collectively, no matter how asymmetrical our relations and how different our positions are.

It is not the school's task to define what the theatre of the future will look like or, in other words, how theatre, performance or the arts in general can keep developing new aesthetics, new ways of making us sensitive to the world and of letting us experience and know the world. In this respect, the students are the ones who have, or rather the one who are building, the knowledge that the schools are supposed to be producing and transmitting. When involved in art schools, we are like the "ignorant schoolmaster" that Jacques Rancière writes about (Rancière 1991),teaching something that we don't know and that we can't know, or rather supporting new generations of artists to undertake their journey, to be bold enough to research into the unknown and strong enough to sustain their practices until they find something, and come back to share it. But how to transmit a knowledge that we don't have, how to support the generation and exchange of knowledge? How to serve a theatre whose aesthetics and languages we don't know yet? How to support forms of spectatorships and of togetherness that we feel emerging but can't recognize yet? How to improve practices of cities and of societies-practices of politics, too-that we can't even imagine yet?

A "what if" exercise is a good way to start exploring this set of questions, because it makes space to deconstruct the existing schools, and imaginatively construct other schools, acting beyond the speculative tension between the possible and the impossible. It is here that fiction comes to our aid as a way to suspend reality. The reality of what art schools are today is not what their real being is or can be, and we cannot access their realness via a critical analysis only. While reality separates us from the real, fiction allows us to access it, if we are willing to engage in a form of collective imagination.

Here we go back to time and to the particular qualities of time required by any form of imagination, by fiction as a suspension of disbelief and by the "as if" attitude that Athanasiou writes about. This 
time is the present time, and cannot be anything else than the complex, thick present time in which we constantly struggle, negotiate, surrender, start again.

Some of the authors exploring the concept of the new and the conditions for its production suggest that the only time that we have to participate in the creation of another reality is the in-between time, the time hidden in the cracks of the present. ${ }^{13}$ And as we know from the theorists of entanglement and cohabitation, we always think or work within given conditions, in precisely situated contexts and with other entities, human and other-than-human, that share and co-create the environment with us. ${ }^{14}$ If the time in which the new can be produced is only the time inbetween other times, and the space that we inhabit is always a shared space coming with specific conditions, then I believe that we can only rethink the art schools by engaging with what they currently are, with their present and their past, working within them and the particular sets of conditions that they provide yet remembering that what they are is not what their real being is, and that only tackling their realness we can affect and transform them.

So, the imaginative bump ends up being a very concrete engagement with what is, a commitment to what is already there and to the present time in which we experience it, rather than a more intriguing leap into the unknown. Perhaps this temporality, this form of being present of the school and to the school, is also where our possibility lies to generate a form of continuity. Not the continuity of an uninterrupted duration though, that seems to be highly utopian under the current conditions of education and of art making, but the continuity given by an intensity of presence that, claiming to be non-negotiable, institutes a locality and calls to an inhabitation of the present time. It is only in the present that we can be at the same time accountable and self-critical, and it is only from this position that the antagonistic tensions that traverse the art schools can be navigated, and an agonistic space can be cultivated that makes the school the democratic institution it could and should be.

\section{Notes}

1 The text is an edited and expanded version of the lecture, Art Schools as Thinking Entities that I gave as a keynote at the Performance Philosophy Conference in Amsterdam, on March 15th, 2019. The original title of my contribution, Art Schools as Thinking Entities, comes from a public conversation I had with some friends and colleagues back in 2015, around Festivals as thinking entities. I would like to credit them-Judith Blackenberg, Daniel Blanga-Gubbay, Livia Andrea Piazza, and Berno Odo Polzer-for that title, and for our shared reflection.

All my thinking is actually built in conversation with others, and the collective effort and the ongoing exchanges that are behind it are very important to me. In particular, I owe some of the inputs for this text to Livia Andrea Piazza, Georg Docker, Barbara van Lindt, Miguel Angel Melgares, and Marijke Hoogenboom, and I would like to thank them for their generosity in exchanging thoughts.

My working is currently embedded within DAS Theatre, the master program of the Amsterdam University of the Arts that I have directed since September 2018. I spoke at the Performance Philosophy conference in Amsterdam, and am writing here, as a practitioner who is trying to better understand some ways of thinking and working, some dynamics and structures, some problems and potentialities of the art school, in order to improve the work that we are doing at DAS, in conversation with others who are engaging in similar questions in different places, within and beyond artistic education. So, all my thoughts are connected to the students, team members, tutors and collaborators of DAS Theatre, without whom I wouldn't have felt the urge to systematize my thoughts around artistic education and the institute of the art school. 
2 Among others, I have been influenced by Blanga, Gubbay, and Piazza (2016) and by Graziano (2016).

${ }^{3}$ Other important references in the discourse about curation in the performing arts are: Davida, Provonost, Hudon, and Gabriels (2018) and Malzacher and Warsza (2017).

${ }^{4}$ Among the others, important references about the institute of the school and the possibility to think of independent, often artist-run education platform are Franceschini (2018), Thorne (2017), Bergman, Salinas, and Boric (2016) and Pomarico (2018). Artistic institutions such as theatre and festivals seem to be more and more keen on reflecting about education, often by organizing free schools: some inspiring example are Santarcangelo Festival and Live Works in Italy, Homo Novus in Latvia, and the Kunstenfestivaldesarts in Belgium.

${ }^{5}$ The concept of agonism has been developed by Mouffe in several books about the political and its dimensions, and in particular about pluralism as a condition for any democratic construction. Among the others, see as references Mouffe $(2005,2013 b)$. She also explored the concept of agonism in relation to artistic and activist practices, see Mouffe (2007). In her writings, Mouffe analyses agonism as a condition for pluralism and, in that sense, as a societal (and we could also say: interpersonal) structure capable of supporting the construction of diverse and democratic environment. It is on this note, that I am referring to this concept and its theoretical and empirical repercussions, in relation to the specific institution of the art school.

${ }^{6}$ This is always the case from the perspective of the directors, teachers or mentors and staff members, but in some cases students also experience it, being involved in decision making and in negotiation processes. In the case of DAS Theatre - the one I can refer to more closely - this mostly happens when some curriculum elements are to be designed by the students as a group. What is called the "Contextual", for example, is a participantscurated course or educational project, allowing participants to shape an environment for mutual learning themselves. Contextual projects can take any form relevant to the topic, theme, methodology or question that has been chosen and as a learning experience. An essential part of the Contextual is the decision-making process towards making a final proposal that is supported by the whole group. Together with a curated curriculum that is never designed in detail at the start of the year, so to keep room for the unexpected and, more precisely, to respond to what happens within the students community, this makes a space for students to (have to) make decisions, to be confronted with their own (conflicting) agendas and with group dynamics, and in the end to embrace disagreement and make effective negotiations in order to design and carry significant process.

7 See among others Kunst (2014) and Han (2015).

${ }^{8}$ Among the attempts that DAS Theatre is making to connect to the socio-political conversation in Amsterdam, is the thematic block programme Broadcasting from Babylon mentored by Amal Alhaag and Maria Guggenbichler in January-March 2019. The block proposed to approach a curricula element of DAS Theatre as a public programme open to everybody in all its part, and took place in various locations within the city of Amsterdam, and particularly in independent, activist and/or artistic spaces where the current discourse around inclusivity is being built, and where practices are experimented and shared, to engage with the issues of race, colour and gender in a multicultural city that only recently started dealing with some aspect of its history and cultural, and in particular with its colonial past and, to a certain extent, present.

${ }^{9}$ An interesting example is the statement published by Ogutu Muraya on Facebook in July 2019. The Kenyan author and theatre maker recently decided, after several years spent in Europe after studying in Amsterdam, to move back to Kenya. His gesture is motivated in his public statement by a strong political stand:

It became difficult, a real challenge for me to convince myself to go through with this periodic process of justifying my existence in order to gain temporary approval from a system that is undeniably discriminatory. A system whose biases and filters disproportionately affect people of colour. I know this decision has consequences for my work and mobility as an artist and person. I will learn to accept the price I have to pay. To reference a different image - it is absurd to always be put in a position where at regular intervals you have to wave your hands shouting - love me, love me - can't you see I am likable and desirable and loyal and faithful to your ways of being. (Muraya 2019) 
10 The image of the holes is inspired by Sarah Vanhee's intervention at the symposium The Fantastic Institution about the art institution as a hole in the ground (Vanhee 2017).

11 The definition of "means with no end" comes from Agamben (1996). Many thinkers have been writing about the political potential of purposeless acts: among others, see Arendt (1958). About the relation between art and the unknown, see also the writings of Rebecca Solnit and in particular Solnit (2005).

12 I am using the term real with reference to the thought of Jacques Lacan, see in particular Lacan (1973).

13 See among others Schneider (2011) and Piazza (2018).

${ }^{14}$ See among others Haraway (2016) and Lowenhaupt Tsing (2015).

\section{Works Cited}

Agamben, Giorgio. 1996. Mezzi senza fine. Note sulla politica. Torino: Bollati Boringhieri (English translation: 2000. Means Without End. Notes on Politics. Translated by Cesare Casarino and Vincenzo Binetti. Minneapolis: University of Minnesota Press).

Arendt, Hannah. 1958. The Human Condition. Chicago: University of Chicago Press.

Athanasiou, Athena. 2016. "Performing the Institution 'As If It Were Possible."' In Former West: Art and the Contemporary After 1989. Edited by Maria Hlavajova and Simon Sheikh, 679-692. Cambridge, MA: MIT Press.

Barad, Karen. 2007. Meeting the Universe Halfway: Quantum Physics and the Entanglement of Matter and Meaning. Durham, NC: Duke University Press. https://doi.org/10.1215/9780822388128

Blanga Gubbay, Daniel and Livia Andrea Piazza. 2016. "Fictional Institutions: On radical Imagination." In Turn Turtle! Reenacting the Institute. Edited by Elke van Campenhout and Lilia Mestre, 40-48. Berlin: Alexander Verlag.

Bergman, Aeron, Alejandra Salinas, and Irena Boric. 2016. Forms of Education: Couldn't Get a Sense of It. Zagreb: Institute for New Connotative Action Press.

Davida, Dena, Marc Provonost, Véronique Hudon, and Jane Gabriels, eds. 2018. Curating Live Arts: Critical Perspectives, Essays and Conversations on Theory and Practice. New York and Oxford: Berghahn. https://doi.org/10.2307/j.ctvw04b29

Douglas, Mary. 1986. How Institutions Think. Syracuse, NY: Syracuse University Press.

Esche, Charles. 2007. How to Grow Possibility: The Potential Roles of Academies. Edited transcript of Charles Esche's talk at the book launch of Air\# Let's suppose the Academy is a place for artists... Amsterdam: Amsterdam School of the Arts.

Franceschini, Silvia, ed. 2018. The Politics of Affinity: Experiments in Art, Education and the Social Sphere. Biella: Cittadellarte.

Fraser, Andrea. 2005. "From the Critique of Institutions to an Institution of Critique." Artforum 44 (1): 278-285.

Han, Byung-Chul. 2015. The Burnout Society. Stanford, CA: Stanford University Press.

Haraway, Donna. 2016. Staying with the Trouble. Making Kin in the Chthulucene. Durham, NC: Duke University Press. https://doi.org/10.1215/9780822373780

Graziano, Valeria. 2016. "Prefigurative Practices. Raw materials for a political positioning of art, leaving the avantgarde." In Turn Turtle! Reenacting the Institute. Edited by Elke van Campenhout and Lilia Mestre, 158-174. Berlin: Alexander Verlag. 
Kunst, Bojana. 2012. "The Project Horizon: On the Temporality of Making." Maska, Performing Arts Journal XXVII: 149-150. Later published in Manifesta Journal around Curatorial Practices. Accessed November 3, 2019. https://www. manifestajournal.org/issues/regret-and-other-back-pages/project-horizon-temporalitymaking

__- 2014. Artist at Work. Proximity of Art and Capitalism. Arlesford: Zero Books.

Lacan, Jacques. 1973. Le séminaire. Livre XI. Les quatre concepts fondamentaux de la psychanalyse. Paris: Le Seuil.

Le Guin, Ursula K. 2017. "Deep in Admiration." In Arts of Living on a Damaged Planet: Ghosts and Monsters of the Anthropocene, Vol 2. Edited by Anna Lowenhaupt Tsing, Heather Anne Swanson, Elaine Gan, and Nils Bubandt, 15-22. Minneapolis: University of Minnesota Press.

Malzacher, Florian, and Joanna Warsza, eds. 2017. Empty Stages, Crowded Flats: Performativity as curatorial strategy. Berlin: Alexander Verlag Berlin.

Mouffe, Chantal. 2005. On the Political. London and New York: Routledge.

. 2007. "Artistic Activism and Agonistic Spaces." Art \& Research. A Journal of Ideas, Contexts and Methods 1 (2) (Summer): n.p. http://www.artandresearch.org.uk/v1 n2/mouffe.html

_-_. 2013a. "Institutions as Sites of Agonistic Interventions." In Institutional Attitudes: Instituting Art in a Flat World. Edited by Pascal Gielen, 63-74. Amsterdam: Valiz.

___. 2013b. Agonistics: Thinking the World Politically. London and New York: Verso.

Muraya, Ogutu. 2019. Facebook, July 27. Accessed on August 1, 2019. https://www.facebook.com/ogutu. muraya

O'Neill, Paul, Lucy Steeds, and Mick Wilson, eds. 2017. How Institutions Think: Between Contemporary Art and Curatorial Discourse. Cambridge, MA: MIT Press.

Pasolini, Pier Paolo. 1964. Io sono una forza del passato in Poesia in forma di rosa. Milano: Garzanti.

Piazza, Livia Andrea. 2018. The Concept of the New. Framing Production and Value in Contemporary Performing Arts. Leverkusen: Verlag Barbara Budrich. https://doi.org/10.2307/j.ctvdf04gv

Pomarico, Alessandra, ed. 2018. Pedagogy, Otherwise: The Reader. Udaipur: Ecoversities.

Rancière, Jacques. 1991. The Ignorant Schoolmaster: Five Lessons in Intellectual Emancipation. Stanford, CA: Stanford University Press.

Schneider, Rebecca. 2011. Performing Remains: Art and War in Times of Theatrical Reenactment. New York and London: Routledge. https://doi.org/10.4324/9780203852873

Solnit, Rebecca. 2005. A Field Guide to Getting Lost. New York: Penguin.

Stengers, Isabelle. 2011. "'Another Science is Possible!' A Plea for Slow Science." Lecture, Faculty of Philosophy and Literature, Université libre de Bruxelles, December 13.

Thorne, Sam. 2017. School: A Recent History of Self-Organized Art Education. Berlin and New York: Sternberg Press.

Tsing, Anna Lowenhaupt. 2015. The Mushroom at the End of the World. On the Possibility of Life in Capitalist Ruins. Princeton: Princeton University Press. https://doi.org/10.1515/9781400873548

Vanhee, Sarah. 2017. 'The Fantastic Institution'. Talk at The Fantastic Institution, Kunstencentrum BUDA, Kortijk, February 16. Accessed November 3, 2019. https://www.kunsten.be/dossiers/perspectief-kunstenaar/ perspective-institution/4451-the-fantastic-institutions

Woolf, Virginia. 1929. A Room on One's Own. London: Hogarth Press. Accessed November 3, 2019. https://ebooks.adelaide.edu.au/w/woolf/virginia/w91r/complete.html

1938. Three Guineas. London: Hogarth Press. Accessed November 3, 2019. https://www.blackwellpublishing.com/content/BPL_Images/Content_store/Sample_chapter/9780631177 241/woolf.pdf 
Silvia Bottiroli, PhD, is a curator, researcher, organizer and educator in the field of performing arts. Since 2018 she is the artistic director of DAS Theatre in Amsterdam. Between 2012 and 2016 she directed Santarcangelo Festival and in 2018 curated the programme 'The May Events' for KunstenFestivalDesArts in Brussels and Vooruit in Ghent. She is interested in the intersections between theoretical research, curatorial practices and education. In these fields she has written numerous articles, focusing in particular on the politics of performativity and spectatorship. She has (co)curated artistic, discursive and educational platforms, collaborating among others with Aleppo, in Brussels Homo Novus Festival in Riga, School of Visual Theatre in Jerusalem and Gent University. Since 2011 she teaches Methodology, Critique and Research in the Arts at Bocconi University in Milan.

(c) 2020 Silvia Bottiroli

Except where otherwise noted, this work is licensed under a Creative Commons AttributionNonCommercial-ShareAlike 4.0 International License. 